\title{
Teaching Vocational with Technology: A Study of Teaching Aids Applied in Malaysian Vocational Classroom
}

\author{
Anesman B. W. Abdul Rahman, Mohd Azlan Mohammad Hussain* and \\ Rafeizah Mohd Zulkifli \\ Universiti Pendidikan Sultan Idris \\ Malaysia \\ https://orcid.org/0000-0001-8491-6283 \\ https://orcid.org/0000-0001-9760-1010 \\ https://orcid.org/0000-0002-3621-2668
}

\begin{abstract}
The Electronic Hardware Repair and Maintenance Course (EHRM) is one of vocational courses at Malaysian Vocational Colleges which have theoretical concepts that students find difficult to understand. Thus, implementation of technological teaching aids (TA) has been expected to help teachers better explain the theoretical concept in this course. The purpose of this study was to identify the various teaching aids applied in EHRM learning sessions as well as to study the usage level of technological teaching aids. This quantitative study was conducted using the questionnaire as the research instrument, the data were analysed descriptively then were reported in percentage and mean. The samples of the study involved 360 students and 106 teachers in the field of Electronic Technology at Malaysian vocational colleges. The findings show that the most widely technological teaching aids used by the Malaysian Vocational college teachers in EHRM classes are radios, televisions, computers and LCD projectors. However, this study found that the use of online material, such as websites, in the EHRM Course is still at low level. This study also indicates that the overall usage of teaching aids in EHRM classes is still at moderate level. Based on the outcome of the study, teaching and learning of EHRM course in Malaysian vocational colleges have been suggested to increase the level of technological teaching aids usage, especially by utilising online-based learning resources to make class sessions more interesting as well as enhancing the student learning outcomes.
\end{abstract}

Keywords: teaching aids; vocational college; electronic technology; teaching vocational courses 


\section{Introduction}

Industries' activity and demand in skills are changing rapidly so vocational education programmes need sufficient transformation to keep on top of these developments (Zulkifli, Mohammad Hussain, Hanapi, Suhairom \& Wahid, 2018). In Malaysia, Vocational Education Transformation is an initiative undertaken aimed at strengthening the vocational education system to make Malaysia become a high-income nation. One of the steps taken by the Ministry of Education Malaysia in transforming vocational education was by upgrading vocational secondary schools to vocational colleges starting in 2012 by offering programmes of studies at the vocational certificate and diploma levels as early as 16 years old. Vocational college study programmes consist of two years at the certificate level (Malaysian Vocational Certificate) and two years and six months at the diploma level (Malaysian Vocational Diploma), including five months of industrial training.

The introduction of vocational colleges in Malaysia has led to the comprehensive curriculum changes based on current industry and market needs (Bidin \& Kamin, 2013). As a result, the curriculum has adopted a new curriculum standard known as the Vocational College Standard Curriculum (VCSC). This change has created many new courses in the Malaysian vocational college system. The new courses introduced are in line with the current rapid advances in technology, especially in the Electronic Technology programme. However, the question that arises is whether the transformation will lead to a better change in teaching and learning process conducted by teachers. Based on the survey conducted by Abdul Rahman et al. (2015), there are three constraints faced by vocational college teachers and students during the PdPc process, which are: time constraints, inadequate and not up-to-date equipment and students being bored easily. Besides that, according to Ishar (2012), lack of appropriate teaching aids is one of the concerning issues in vocational college, which causes students in having difficulties in understanding a learning concept. Majumdar (2009) also mentioned that pedagogy of vocational education is still ineffective, does not fulfil industry requirements and needs a strategy so that knowledge and skills can be applied during the teaching and learning process.

Among the many vocational courses available, one of them is the Electronic Hardware Repair and Maintenance Course (EHRM). The EHRM course includes the topics of Colour TV Receiver and Radio Receiver which have a theoretical concept that is difficult to be explained to students during the lesson (Jamaludin, 2014). Thus, implementation of technological-based teaching aids has been expected to help teachers better explain the theoretical concept in these courses compared to the traditional "chalk and talk" teaching approach. The use of teaching aids is important to enhance students' understanding while maintaining their learning interest (Azman, Azlee, Musttapha, Balakrishnan \& Mohd Isa, 2014). For example, the use of gamification in a teaching and learning session has shown positive achievement in the attitude, motivation and perception of the vocational college students (Ismail, Sa'adan, Samsudin, Hamzah, Razali \& Mahazir, 2018). A suitable teaching aid in teaching and learning session also will able to increase students' focus on teaching and learning session (Jasmi, Ilias, Tamuri \& Mohd Hamzah, 2011). The use of teaching aids can also have a positive impact on 
students' academic excellence and teachers' teaching methods (Hamdan \& Mohd Yasin, 2010; Ilias, Husain, Noh, Rashed \& Abdullah, 2016 ). In short, literatures and studies indicate that students' learning session can be improved by applying appropriate teaching aids during the lesson.

Therefore, this research have been conducted to study the frequency and quality teaching aids used by Malaysian vocational college teachers in the Electronic Technology programme, specifically on the EHRM Course. Other than that, this study is also conducted to identify which technological and online based teaching aids were used by Malaysian vocational college teachers. This is because, according to studies conducted by previous researchers, the use of technological tools and ICT in teaching enables to improve the students' understanding on the concepts that have been taught (Mohd Hashim \& Abubakar, 2017), diversifies learning activities (Hasnuddin, Norfaizuryana \& Nor Azzarahton, 2015), positively impacts students' attitude, motivation and achievement (Iberahim, Mahamod \& Man Mohammad, 2017), as well as improves students' performance, knowledge and skills (Higgs, Barnett, Billett, Hutchings \& Trede, 2013). Therefore, this study is necessary to ensure the teaching staff at $\mathrm{VC}$ are not left behind in applying technology-related TA to enhance the effectiveness of teaching and learning.

\section{Research methodology}

This study has been conducted using the quantitative method. The questionnaires were used as an instrument for data collection and the data were analysed using descriptive analysis. The results of the study were reported in percentage and mean.

\subsection{Research sampling}

There were two groups of sampling involved in this study, students group and teachers group. Student samples were selected using the stratified random sampling method. The vocational college selection was categorised by zones consisting of Southern Zone, Eastern Zone, Central Zone, Northern Zone, Sabah Zone and Sarawak Zone. The stratified random sampling was chosen for the student samples because this type of sample is most suitable for the zone, state, division, and district-based studies or sample selection based on several categories (Yusri, Rahimi, Shah, Abdul Majid \& Wah, 2012). According to the enrolment, the total number of Electronic Technology students in the third semester of second year at Malaysia vocational colleges in 2019 is 1,118 students (Malaysia Ministry of Education, 2019). Hence, a suitable sample size according to Krejcie and Morgan (1970) is no less than 291 students. Thus, the total student sample of this study was fixed at 360 students, which was more than the sample size proposed by Krejcie and Morgan (1970).

The sampling method used for the teacher was simple random sampling. Vocational college selection was categorised by zones. Then, two vocational colleges were selected for each zone through simple random sampling to obtain the teaching staff sample. The simple random sampling was selected on the sample of the teaching staff because this method was fairer to the population. Therefore, the sample of the teaching staff involved in this study was 106 Electronic Technology teaching staff at vocational colleges. 


\subsection{Research instrument}

The instrument used in this study consisted of two sets of questionnaires for students and teachers of the Electronic Technology programme. The contents of the items in both surveys are the same. The instrument was adapted with consent from the previous researcher, Burhan (2016). Questionnaire items for students and the teaching staff were constructed using the five-point Likert scale as shown in Table 1.

Table 1. Five-point Likert scale

\begin{tabular}{cc}
\hline Likert & Classification \\
\hline 1 & Never \\
2 & Rarely (Once in 6 weeks) \\
3 & Sometimes (Once in 4 weeks) \\
4 & Often (Once in 2 weeks) \\
\hline 5 & Very Often (Every week) \\
\hline
\end{tabular}

\subsection{Validity and reliability}

The validity and reliability of the instrument are intended to maintain the precision of the instrument (Dimopoulos, Paraskevopoulos \& Pantis, 2009). Therefore, the validity of the instrument was performed by five experts who were appointed for the purpose of face and content validity. The selection of five experts was in accordance with the suggestions given by Makki, Khalick, and Boujoude (2003) and Dimopoulos, Paraskevopoulos, and Pantis (2009) in which they asserted that at least three experts in the field of expertise are needed for verification of item content. Thus, the number of specialists selected was more than three. The specialists selected were educational technology specialist, technical and vocational education specialist, electrical and electronic engineering specialist and language specialist. The expertise of the specialists was also taken into account based on their experience of more than 10 years in their own field.

A pilot study had to be conducted to identify reliability of the questionnaire used in this study. The pilot questionnaire will be evaluated on its reliability as to whether the questionnaire is suitable for the actual study, or vice-versa. According to Hair and his colleagues (2016), the expected reliability value and Cronbach's Alpha is $>0.7$, while 0.6 is still considered. A pilot study of the student questionnaire was conducted at a vocational college in the Federal Territory of Kuala Lumpur involving 50 Electronic Technology students who had previously taken the EHRM course. Meanwhile, a pilot study for the teaching staff questionnaire was conducted at four separate vocational colleges from a separate zone. Therefore, the total number of teaching personnel from the four vocational colleges is 51. The selection of the four vocational colleges for the pilot study of the teaching staff questionnaire was due to the fact that each VC has less than 10 teaching staff teaching Electronic Technology. The total samples of the pilot study for both forms of the survey are based on the suggestion given by Johanson and Brooks (2010) who stated the total sample number of a pilot study must not be less than 30. A result from pilot study show that The Cronbach's alpha value for the student questionnaire was 0.802 and for the teaching staff questionnaire was 0.804. Since Cronbach's alpha value was larger than 7.0, the questionnaire has been proved reliable to be used for the actual study study. 
A total of 454 student questionnaires and 113 teaching staff questionnaires was distributed in the actual study. However, only 360 student questionnaire forms were required, while for the teaching staff questionnaire forms, only 106 were completed and returned. Accordingly, a total of 466 student and teaching staff questionnaires was processed and analysed using the 'Statistical Package for Social Science (SPSS) version 25.0'. The Cronbach's alpha value of the student questionnaire in the actual study was 0.71 and for the teaching staff questionnaire was 0.78 .

\subsection{Data analysis}

The data were analysed using descriptive analysis. According to Sekaran and Bougie (2016), descriptive statistics can be used to describe an ongoing phenomenon. Hence, the researchers used the Statistical Packages for Social Sciences Version 25.0 (SPSS) software to identify the frequency and the usage level of teaching aids during EHRM Course teaching and learning session. The results of the studies are reported in the form of percentage and mean. For this purpose, the mean interpretation used is shown in Table 2.

Table 2. Interpretation of mean range value

\begin{tabular}{cc}
\hline Mean Score & Level \\
\hline 1.00 to 2.33 & Low \\
2.34 to 3.67 & Moderate \\
3.68 to 5.00 & High \\
\hline
\end{tabular}

Source: Wiersma (2000)

\subsection{Result}

Table 3 shows the percentage and level of teaching aids used in EHRM classes based on the students' perceptions. The table shows that printed materials had the highest usage with a mean score of 4.56. In addition, the use of technologicalbased teaching aids, including LCD projectors and computers, also showed high levels of usage among the Electronic Technology teachers, each with a mean score of 3.91 and 3.77, respectively. The level of usage on teaching aids, including roller boards, models, televisions, radios and actual equipment, was at the moderate level with each having mean scores of 3.53, 3.44, 3.27, 3.23 and 3.21, respectively. Judging by the usage percentage, these teaching aids have a percentage value of less than $47.3 \%$ in the categories of frequent and most frequently used. The study also found that magnetic boards was less popular to be used in the teaching and learning of the EHRM course with a mean score of 1.22 and $77.8 \%$ of those who responded rated the magnetic board as 'never used'. This was followed by game materials, flash cards, charts, compact discs, transparencies, websites, pictures and overhead projectors (OHP) which also had low usage levels, each with mean scores of 1.40, 1.54, 1.74, 2.03, 2.04, 2.28, 2.32 and 2.33, respectively. Meanwhile, the usage frequency percentage of these teaching aids did not exceed 10. 
Table 3. Mean and percentage of teaching aids usage based on student perception

\begin{tabular}{|c|c|c|c|c|c|c|c|c|}
\hline \multirow{2}{*}{ No } & \multirow{2}{*}{ Item } & \multicolumn{5}{|c|}{ Score $(\%)$} & \multirow{2}{*}{ Mean } & \multirow{2}{*}{ Level } \\
\hline & & 1 & 2 & 3 & 4 & 5 & & \\
\hline 1 & $\begin{array}{l}\text { Printed } \\
\text { materials }\end{array}$ & 1.1 & 1.9 & 6.7 & 20.6 & 69.7 & 4.56 & High \\
\hline 2 & Writing boards & 1.1 & 1.7 & 6.1 & 25.8 & 65.3 & 4.53 & High \\
\hline 3 & LCD projectors & 2.8 & 4.2 & 20.3 & 45.0 & 27.8 & 3.91 & High \\
\hline 4 & Computers & 1.9 & 6.4 & 25.0 & 45.8 & 20.8 & 3.77 & High \\
\hline 5 & Roller boards & 0 & 0.3 & 52.5 & 41.7 & 5.6 & 3.53 & Moderate \\
\hline 6 & Models & 3.9 & 13.9 & 28.3 & 42.5 & 11.4 & 3.44 & Moderate \\
\hline 7 & Televisions & 0 & 5.8 & 61.4 & 32.8 & 0 & 3.27 & Moderate \\
\hline 8 & Radios & 0 & 9.7 & 59.4 & 29.4 & 1.4 & 3.23 & Moderate \\
\hline 9 & $\begin{array}{l}\text { Actual } \\
\text { equipment }\end{array}$ & 0 & 10.0 & 60.8 & 27.5 & 1.7 & 3.21 & Moderate \\
\hline 10 & $\begin{array}{l}\text { Overhead } \\
\text { projectors } \\
(\mathrm{OHP})\end{array}$ & 21.7 & 34.7 & 34.4 & 7.5 & 1.7 & 2.33 & Low \\
\hline 11 & Pictures & 17.8 & 46.1 & 23.9 & 10.8 & 1.4 & 2.32 & Low \\
\hline 12 & Websites & 1.7 & 69.2 & 28.9 & 0.3 & 0 & 2.28 & Low \\
\hline 13 & Transparencies & 33.9 & 42.8 & 11.1 & 9.7 & 2.5 & 2.04 & Low \\
\hline 14 & Compact Discs & 29.7 & 45.0 & 18.3 & 6.4 & 0.6 & 2.03 & Low \\
\hline 15 & Charts & 43.6 & 41.1 & 13.3 & 1.1 & 0.8 & 1.74 & Low \\
\hline 16 & Flash cards & 55.3 & 37.8 & 5.0 & 1.7 & 0.3 & 1.54 & Low \\
\hline 17 & Game materials & 70.0 & 22.5 & 5.8 & 0.8 & 0.8 & 1.40 & Low \\
\hline 18 & $\begin{array}{l}\text { Magnetic } \\
\text { boards }\end{array}$ & 77.8 & 22.2 & 0 & 0 & 0 & 1.22 & Low \\
\hline
\end{tabular}

Note: 1: Never 2: Rarely 3: Sometimes 4: Often 5: Very Often

$\mathrm{N}=360$

As a comparison, Table 4 shows the frequency and level of teaching aids usage based on the teachers' perception. The table indicates that the teaching aid with the highest usage level was the writing board with a mean score of 4.38 and a high usage frequency percentage of $90.6 \%$ in the categories of 'often' and 'very often'. In addition, the use of technological-based teaching aids, including computers, LCD Projectors, radios, and televisions also indicated a high level of use among the teaching staff of Electronic Technology and with a usage frequency percentage of over $70 \%$.

In addition, the usage level of learning materials, such as actual equipment, models, pictures, roller boards, and charts, was moderate with each having mean scores of 3.33, 3.15, 3.11, 2.93 and 2.63, respectively. The magnetic boards' usage was less popular to be applied in EHRM course, with the level of usage was only at a mean score of 1.17 and this TA also had a high percentage of $86.8 \%$ of never been used. This finding is similar to the finding from the students' analysis that the use of magnetic boards was the lowest used by teachers in EHRM course. Meanwhile, transparencies, overhead projectors (OHP), compact discs, flash cards, websites and game materials were among the lowest used TA with each having mean scores of 1.48, 1.75, 1.93, 2.02, 2.03 and 2.15, respectively. In 
conclusion, the level of teaching aids used in EHRM course classes is at a moderate level based on the students' and teachers' perception.

Table 4. Mean and percentage of teaching aids usage based on teachers' perception

\begin{tabular}{|c|c|c|c|c|c|c|c|c|}
\hline \multirow{2}{*}{ No } & \multirow{2}{*}{ Item } & \multicolumn{5}{|c|}{ Score $(\%)$} & \multirow{2}{*}{ Mean } & \multirow{2}{*}{ Level } \\
\hline & & 1 & 2 & 3 & 4 & 5 & & \\
\hline 1 & Writing boards & 0 & 0 & 9.4 & 43.4 & 47.2 & 4.38 & High \\
\hline 2 & Computers & 0.9 & 1.9 & 9.4 & 35.8 & 51.9 & 4.36 & High \\
\hline 3 & LCD projectors & 0 & 0.9 & 15.1 & 38.7 & 45.3 & 4.28 & High \\
\hline 4 & $\begin{array}{l}\text { Printed } \\
\text { materials }\end{array}$ & 0 & 0 & 21.7 & 69.8 & 8.5 & 3.87 & High \\
\hline 5 & Radios & 0 & 0 & 27.4 & 59.4 & 13.2 & 3.86 & High \\
\hline 6 & Televisions & 0 & 0 & 30.2 & 56.6 & 13.2 & 3.83 & High \\
\hline 7 & $\begin{array}{l}\text { Actual } \\
\text { equipment }\end{array}$ & 0 & 4.7 & 59.4 & 34.0 & 1.9 & 3.33 & Moderate \\
\hline 8 & Models & 7.5 & 16.0 & 38.7 & 29.2 & 8.5 & 3.15 & Moderate \\
\hline 9 & Pictures & 15.1 & 15.1 & 27.4 & 28.3 & 14.2 & 3.11 & Moderate \\
\hline 10 & Roller boards & 0 & 29.2 & 50.0 & 18.9 & 1.9 & 2.93 & Moderate \\
\hline 11 & Charts & 17.9 & 27.4 & 33.0 & 17.0 & 4.7 & 2.63 & Moderate \\
\hline 12 & $\begin{array}{l}\text { Game } \\
\text { materials }\end{array}$ & 37.7 & 25.5 & 23.6 & 10.4 & 2.8 & 2.15 & Low \\
\hline 13 & Websites & 16.0 & 65.1 & 18.9 & 0 & 0 & 2.03 & Low \\
\hline 14 & Flash cards & 46.2 & 20.8 & 20.8 & 9.4 & 2.8 & 2.02 & Low \\
\hline 15 & Compact Discs & 47.2 & 23.6 & 18.9 & 9.4 & 0.9 & 1.93 & Low \\
\hline 16 & $\begin{array}{l}\text { Overhead } \\
\text { projectors } \\
(\mathrm{OHP})\end{array}$ & 61.3 & 16.0 & 10.4 & 11.3 & 9 & 1.75 & Low \\
\hline 17 & Transparencies & 71.7 & 15.1 & 8.5 & 2.8 & 1.9 & 1.48 & Low \\
\hline 18 & $\begin{array}{l}\text { Magnetic } \\
\text { boards }\end{array}$ & 86.8 & 9.4 & 3.8 & 0 & 0 & 1.17 & Low \\
\hline
\end{tabular}

Note: 1: Never 2: Rarely 3: Sometimes 4: Often 5: Very Often $\mathrm{N}=360$

In order to clearly compare teaching aids used in the EHRM course based on the students' and teachers' perception, Figure 1 shows both groups of respondents' mean score using the bar chart. Based on the graph, there is no significant difference between the results of the analysis obtained from the students and the teaching staff in regard of types of teaching aids used in their EHRM course teaching and learning. 


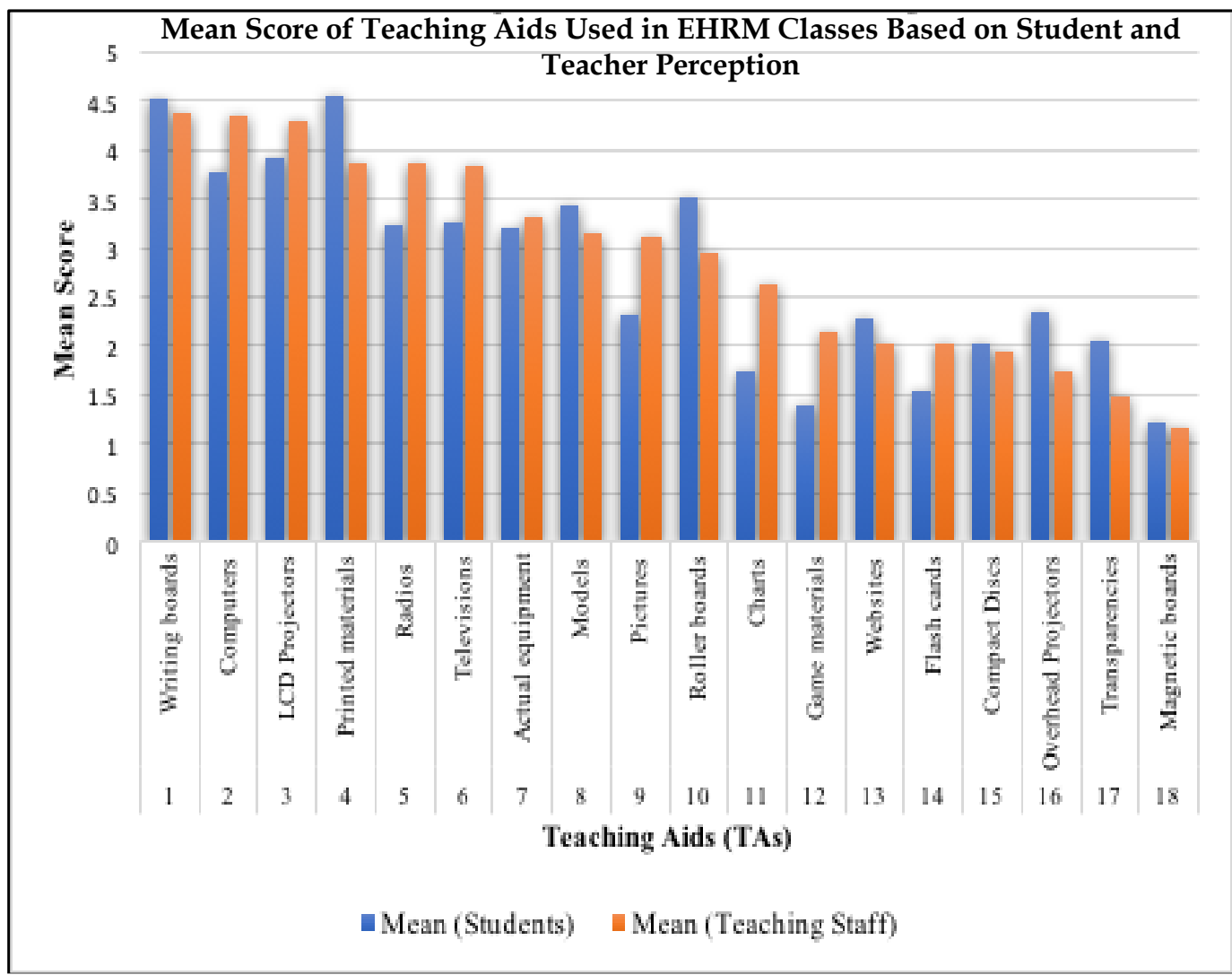

Figure 1. Comparison of teaching aids used in the EHRM course based on the students' and teachers' perception

\section{Discussion}

This study has discovered that printed materials were the most frequently used teaching aids by the teachers based on students' perceptions. The findings of this study are in line with the findings of Hamdan and Mohd Yasin (2010), who found that the use of printed materials had a high level of usage among teachers of technical schools in the district of Johor, Malaysia. However, there is a difference in the perceptions of the teachers in which writing boards were most frequently used in teaching and learning of the EHRM course. This finding is consistent with Ashaver and Igayuve (2013), who found that writing boards are the only significant teaching material used by lecturers at Katsina-Ala College of Education in Nigeria. Nevertheless, both teaching materials are still the highest used teaching aids in terms of the frequency of use in the EHRM course. According to Hamdan and Mohd Yasin (2010) regarding the use of printed materials, the highest frequency of this teaching aid is because they are easier, simpler and time-saving to prepare as, normally, the printing job is done by office assistants in schools. In addition, the attitude of some of the teaching staff who refuse to make changes in their teaching and learning process also contributes to the increased use of printed materials, as they prefer to use existing learning materials without having to innovate their teaching and learning session. Likewise, with the use of writing boards, whereby the teaching staff prefer to use them as they are always available in the lecture rooms or classrooms. 
Meanwhile, the use of roller boards, models, pictures, charts and actual equipment recorded a moderate usage level by students and the teaching staff of Electronic Technology. This is in proportion to the studies of Shya (2004) and Hamdan and Mohd Yasin (2010) which shows that the level of teaching aids used was at a moderate level achieved by the respondents in their studies of technical teachers at a technical secondary school. Moreover, the use of television and radio is also at a moderate level based on students' perceptions. On the contrary, the use of television and radio is at a high level from the teachers' perceptions. This is because the EHRM course has topics related to television and radio receivers that require the teaching staff to use them as a student practical activity.

According to Zulkifli, Mohammad Hussain, Abd Wahid, and Che Rus (2019), teaching and learning in vocational courses were expected to be conducted using the $21^{\text {st }}$ century teaching and learning activities which focused on student-based learning supported by sufficient technologies. The 21st-century teaching and learning also requires teachers to be competent in computer usage because 21stcentury learning involves the use of the internet in the teaching and learning. Hence, this study shows that the use of technological-based teaching aids, including computers and LCD projectors, among the Electronic Technology teaching staff has a high level of usage based on the students' and teaching staff's perceptions. This shows that the teaching staff at vocational colleges are ready for 21st-century learning. However, this does not imply that the Electronic Technology teachers practising 21st-century learning in their class as the findings on the use of websites in the EHRM Course are at a low level. Thus, the frequent use of computers and LCD projectors in the teaching and learning of the EHRM course is likely due to the teaching staff preferring to use PowerPoint slides in their teaching and learning activities. In the meantime, the use of overhead projectors, transparencies, magnetic boards, compact discs, flash cards and game materials recorded low levels of use by the Electronic Technology teachers at vocational colleges. Among those teaching aids, magnetic boards had the lowest usage level in the teaching and learning activities. It is possible that the teaching staff are not interested in this teaching aid, or there are vocational colleges that still do not provide this teaching aid as there is not any need in their teaching activities.

The result of the study also indicates that the level of teaching aids usage among the Electronic Technology teachers at vocational colleges is still moderate. The findings of this study are in line those obtained from Hamdan and Mohd Yasin (2010), who carried out a study on the use of learning materials by technical teachers at a technical secondary school in Johor Bahru. This situation indicates that the level of use of teaching aids among vocational teachers is still at a moderate level, despite the transformation of vocational secondary schools since 2012. Therefore, it is advisable for the relevant authorities to take action so that the use of technological teaching aids among vocational teachers can be further enhanced; this is in line with the current educational developments in order to have a better impact on student learning.

As a suggestion, an immediate step that can be taken to encourage the use of technological-based teaching aids, such as computers and the internet, as the 
current learning trend is based on web 2.0 technology which requires teachers and students to apply ICT in their teaching and learning. In the context of this study, the findings show that computer usage is at a high level, while internet use, such as web usage, is still at a low level. This situation gives the impression that the Electronic Technology teachers at vocational colleges have yet to fully implement learning based on the web 2.0 technology. Therefore, a study needs to be conducted to look at the level of internet access facilities at the Malaysian Ministry of Education's vocational colleges, as well as the level of acceptance of students and the teaching staff in applying the web 2.0 technology in the teaching and learning of the EHRM course.

\section{Conclusions}

In conclusion, although the conventional teaching aids, including writing board and printed materials, are still popular in the Electronic Hardware Repair and Maintenance class setting, there were several technological teaching aids being widely used in this course, which are radios, televisions, computers and LCD projectors. However, the most important finding of the study is the fact that the use of online material, such as websites, in the EHRM course is still at a low level. This finding indicates that vocational teachers are still not in line with the latest trend of technological teaching aids in a $21^{\text {st }}$ century classroom which utilise the online media as a source of information, teaching activities as well as a new way of students-teacher interaction. Hence, the use of technological-based teaching aids should be heightened, especially the use of the internet, in teaching and learning to make learning more interesting and effective in enhancing student learning outcomes in the EHRM course. Other than that, vocational college teachers need to be exposed to adequate training to ensure they are skilled in the new methods of teaching and learning use of the latest technology tools, and diversifying their teaching methods. These are to ensure that students learning session in EHRM course can be effectively implemented.

\section{Acknowledgement}

This research study was supported by the 2018 Universiti Pendidikan Sultan Idris Inovation Research Grant. The title of the study is "The Development of Selfcentered Arduino Microprocessor Learning Module for Minor Students in Design and Technology Program, FTV" (2018-0177-107-01).

\section{References}

Abdul Rahman, K. A., Saud, M. S., Kamin, Y., \& Abu Samah, N. (2015). Masalah dalam pengajaran dan pembelajaran bagi kursus Teknologi Elektrik di kolej vokasional [Issues in teaching and learning of the electrical technology course at vocational colleges]. In: International Education Postgraduate Seminar 2015, 20-21 Dec, 2015, Johor Bahru, Johor. Retrieved from https://pdfs.semanticscholar.org/542f/c39ec83cd6d8408226dcdbd9518c136a365 c.pdf

Ab Rahman, H., Zainal, N., \& Ab Karim, N. A. (2015). Keberkesanan penggunaan ict di dalam pengajaran dan pembelajaran pendidikan islam bagi Sekolah Kebangsaan Desa Pandan Kuala Lumpur [The effectiveness of ICT usage in teaching and learning of Islamic education subject for Desa Pandan Primary school, Kuala Lumpur]. International Conference on Information Technology \& Society. 8-9 June 
2015, Kuala Lumpur, Malaysia. Retrieved from https://docplayer.net/30631274Keberkesanan-penggunaan-ict-di-dalam-pengajaran-dan-pembelajaranpendidikan-islam-bagi-sekolah-kebangsaan-desa-pandan-kuala-lumpur.html

Amadioha, S. (2009). The importance of instructional materials in our schools an overview. New Era Research Journal of Human, Educational and Sustainable Development, 2(3), 49.

Ashaver, D., \& Igyuve, S. M. (2013), The Use of Audio-Visual Materials in the Teaching and Learning Processes in Colleges of Education in Benue State-Nigeria. IOSR Journal of Research \& Method in Education, 1(6), 44-55. https:// doi.org/10.9790/7388-0164455

Azman, M. N. A., Azlee, N. A., Mustapha, R., Balakrihsnan, B., \& Mohd Isa, N. K. (2014). Penggunaan alat bantu mengajar ke atas guru pelatih bagi topik kerja kayu, paip dan logam [The use of teaching aids among pre-service teachers on the topic of wood, pipe and metal works]. Sains Humanika, 3(1), 77-85. Retrieved from https:// sainshumanika.utm.my/index.php/sainshumanika/article/view/530

Biden, N., \& Kamin, Y. (2013). Implikasi penjenamaan semula Sekolah Menengah Vokasional (SMV) kepada Kolej Vokasional (KV) [The rebranding implications of Sekolah Menengah Vocational (SMV) to vocational College (KV)]. 2nd International Seminar on Quality and Affordable Education (ISQAE 2013), (Isqae), 316323. Retrieved from https://educ.utm.my/wpcontent/uploads/2013/11/44.pdf

Burhan, N. (2016). Pembangunan dan penilaian modul kursus Tamadun Islam dan Tamadun Asia (e-citac) berasaskan strategi blended learning [Development and evaluation of the course module for Islamic civilization and Civilization Asia (e-CITAC) based on blended learning strategy]. [Unpublished doctoral dissertation]. Universiti Kebangsaan Malaysia.

Darusalam, G., \& Hussin, S. (2018). Metodologi penyelidikan dalam pendidikan [Research methodology in education] ( $2^{\text {nd }}$ ed.). Kuala Lumpur: Universiti Malaya.

Dimopoulos, D. I., Paraskevopoulos, S., \& Pantis, J. D. (2009). Planning educational activities and teaching strategies on constructing a conservation educational module. International Journal of Environmental and Science Education, 4(4), 351-364. Retrieved from https://eric.ed.gov/?id=EJ884402

Hair Jr, J. F., Hult, G. T. M., Ringle, C., \& Sarstedt, M. (2016). A primer on partial least squares structural equation modeling (PLS-SEM). Sage publications.

Hamdan, A. R., \& Mohd Yasin, H. (2010). Penggunaan alat bantu mengajar (abm) di kalangan guru-guru teknikal di Sekolah Menengah Teknik daerah Johor Bahru, Johor [The use of teaching aids among Technical High Schools in Johor Bahru region, Johor] [Bachelor Thesis]. Universiti Teknologi Malaysia. Retrieved from http://www.fp.utm.my/ePusatSumber/pdffail/ptkghdfwP/HAYAZIAP05037 2D2008TTP.pdf

Higgs, J., Barnett, R., Billett, S., Hutchings, M., \& Trede, F. (Eds.). (2013). Practice-based education: Perspectives and strategies (Vol. 6). Springer Science \& Business Media.

Ilias, M. F., Husain, K., Noh, M. A. M., Rashed, Z. N., \& Abdullah, M. (2016). Sumber bahan bantu mengajar dalam kalangan guru Pendidikan Islam Sekolah Bestari [Teaching aids sources among Islamic education teachers in the Bestari School]. eAcademia Journal, 5(2). Retrieved from http:// myjms.moe.gov.my/index.php/JeA/article/view/1301

Ishar, A. (2012). Kesan inovasi MTEP LK dalam pengajaran dan pembelajaran lukisan kejuruteraan dalam kalangan pelajar tingkatan empat di Sekolah Menengah Teknik [An effect of MTEP LK innovation on teaching and learning of Engineering Drawing subject among the form-four students at the Technical High School]. [Unpublished doctoral dissertation]. Universiti Kebangsaan Malaysia. 
Ismail, M. E., Sa'adan, N., Samsudin, M. A., Hamzah, N., Razali, N., \& Mahazir, I. I. (2018). Implementation of the gamification concept using KAHOOT! among TVET students: An observation. Journal of Physics: Conference Series, 1140(1), 12-13. https:// doi.org/10.1088/1742-6596/1140/1/012013

Jamaludin, J. (2014), Kesediaan guru kolej vokasional dalam pengajaran amali teknologi elektronik di negeri Pahang. [The readiness of vocational college teachers to teach practical activities in Electronic Technology Subject] [Master's Thesis]. Universiti Tun Hussein Onn Malaysia. Retrieved from https://core.ac.uk/download/pdf/42955437.pdf

Jasmi, K. A., Ilias, M. F., Tamuri A. H., \& Mohd Hamzah, M. I. (2011). Amalan penggunaan bahan bantu mengajar dalam kalangan guru cemerlang Pendidikan Islam Sekolah Menengah di Malaysia [The use of teaching aids among Islamic Education excellent teachers in Malaysian high-schools]. Journal of Islamic and Arabic Education, 3(1), 59-74.

Johanson, G. A., \& Brooks, G. P. (2010). Initial scale development: sample size for pilot studies. Educational and Psychological Measurement, 70(3), 394-400. https://doi.org/10.1177/0013164409355692

Krejcie, R. V., \& Morgan, D. W. (1970). Determining sample size for research activities. Educational and psychological measurement, 30(3), 607-610. https:// doi.org/10.1177/001316447003000308

Majumdar, S. (2009). Major challenges in integrating sustainable development in TVET. Paper presented at the International Conference: Reorienting TVET Policy Towards Education for Sustainable Development, Berlin, Germany. Retrieved from http://www.unevoc.unesco.org/fileadmin/user_upload/docs/402-00022010_lowquality.pdf

Makki, M. H., Abd-El-Khalick, F., \& BouJaoude, S. (2003). Lebanese secondary school students' environmental knowledge and attitudes. Environmental Education Research, 9(1), 21-33. https:// doi.org/10.1080/13504620303468

Malaysia Ministry of Education. (2019). Student enrollment in electronic technology at vocational college. Retrieved from http://www.data.gov.my/data/ms_MY/; Accessed on: 3 April 2019.

Mohd Hashim, M. H., \& Abubakar, B. (2017). The availability of electronic courses using ict infrastructure in teaching and learning among teachers in Nigeria's TVET institutions. Pertanika Journal Social Sciences \& Humanities, 25, 17 - 28. Retrieved from https:// core.ac.uk/download/pdf/153832784.pdf\#page $=33$

Nunnally, J. C., \& Bernstein, I. H. (1994). Psychometric theory (3rd ed.). New York, NY: McGraw-Hill.

Sekaran, U., \& Bougie, R. (2016). Research methods for business: A skill building approach. Chichester, UK: John Wiley \& Sons.

Shya, N. Y. (2004). Penggunaan alat bantu mengajar di kalangan guru-guru teknikal sekolah menengah teknik, negeri Kedah [The use of teaching aids among Kedah high Technical School teachers]. [Unpublished undergraduate thesis]. Universiti Teknologi Malaysia.

Wiersma, W. (2000). Research method in education: An introduction. Needham Heights: Allyn \& Bacon.

Yusri, G., Rahimi, N. M., Shah, P. M., Abdul Majid, M. A., \& Wah, W. H. (2012). Penggunaan bahan pembelajaran dalam kursus Bahasa Arab [Use of learning materials in Arabic subject]. Journal of Language Studies, Journal of Language Studies, 12(1), 215-233. Retrieved from http://ejournals.ukm.my/gema/article/view/30

Zulkifli, R. M., Mohammad Hussain, M. A., Abd Wahid, N. H., Suhairom, N., Che Rus, R. (2019). Implementation of the 21st century learning approach among technical and vocational education trainee teachers. Noh@Seth, N. H., Md Noor, N., Arsat, M., Ali, D. F., Md Nasir, A. N., Abd Wahid, N. H., Kamin. TVET Towards Industrial 
Revolution 4.0: Proceedings of the Technical and Vocational Education and Training International Conference. (59-64). London. Taylor \& Francis Group.

Zulkifli, R. M., Mohammad Hussain, M. A., Hanapi, Z., Suhairom, N., \& Wahid, N. H. A. (2018). Industry-specific knowledge that vocational teachers should know and be able to do to prepare a job-ready workforce. Journal of Engineering Science and Technology, 13, 14-22. Retrieved from http://jestec.taylors.edu.my/Special\%20Issue\%20on\%20ICETVESS_2017/ICET VESS_02.pdf 
Appendix 1

STUDENT NEEDS ANALYSIS QUESTIONNAIRE
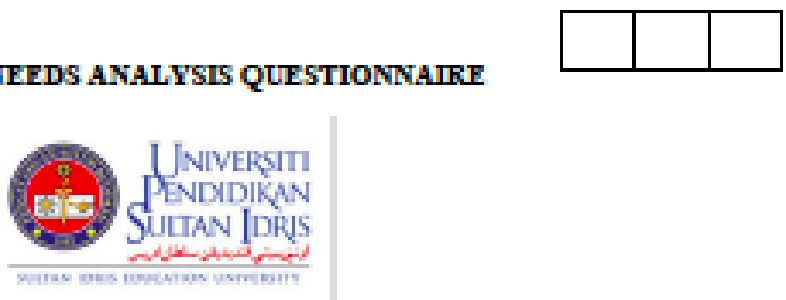

FEEDBACK ON ELECTRONIC TECHNOLOGY STUDENT AT VOCATIONAL COLLEGE FOR DEVELOPMENT NEEDS OF A SPECIALISED LEARNING MODULE BASED ON INQUIRY APPROACH

By:

Anesman Bungraya Wenge bin Abdul Rahman

Faculty of Technical and vocational

Universiti Pendidikan Sultan Idris

This questionnaire is a feasibility analysis study aimed at obtaining students ' feedback on students ' needs for a survey-based learning module for the Repair and Maintenance Course of Electronic Hardware and ETN3033 course code. The study aims to identify the level of use of teaching materials used by trainers based on student perception. Your cooperation is sincere and precisely appreciated. Information provided will be kept confidential and used for the benefit of this study only.

THIS QUESTIONNAIRE CONSISTS OF TWO (2) SECTIONS LE. PART A TO PART B AS FOLLOWS:

PART A: RESPONDENT DEMOGRAPHICS PART B: TEACHING AIDS 


\section{PART A: RESPONDENT DEMOGRAPHICS}

Instructions: Please select one of the only answers and tick $(V)$ in the space provided.

1. Gender

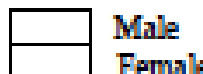

2. Age

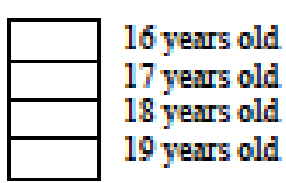

3. Types of phones Owned

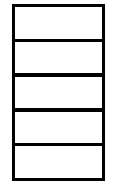

Phone with common keys

No Internet smartphone

Smart phones have Intemet

High Technology phone (iPhone/Tablet/ipad)

Do not have a phone

4. Have a personal computer/laptop

$\square$ Have

No (please proceed to question 6 )

5. If you have a computer, do the computer have Internet access

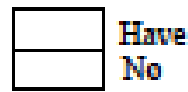

6. Computer skills

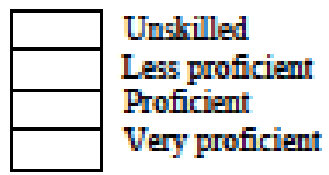

7. My institution learned to have wifi.

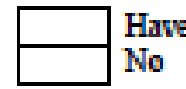


8. Knowledge of information and communication technology (ICT)

\begin{tabular}{|l|l}
\hline & Basic Microsoft Office (word, powerpoint, excel) \\
\hline & Intermediate Microsoft Office \\
\hline Advanced Microsoft Office \\
\hline Have a variety of skills in computer software
\end{tabular}

9. Electronic Hardware Repair and Maintenance Course (ETN3033) has a leaming module?

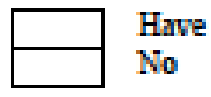

If any, are there any weaknesses or improvements to be done on the module? Please specify:

10. Are there any requirements for the constraction of the learning module for the repair and maintenance courses on electronic hardware online?

Need

No need

If it is necessary, is it important to be implemented in class? Please specify: 


\section{PART B: TEACHING AIDS}

Directions: This section to assess the frequency of teaching aids usage by trainers in the PPPE course.

* Tick $(\sqrt{ })$ your answers based on the frequency scale provided.

\begin{tabular}{|c|c|c|}
\hline Number & $\begin{array}{l}\text { Teaching aids used in the PPPE } \\
\text { course }\end{array}$ & $\begin{array}{l}\text { Usage Frequency scale: } \\
\text { 1. Never } \\
\text { 2. Infrequently (once in } 6 \text { weelss) } \\
\text { 3. Sometimes (once in } 4 \text { weelss) } \\
\text { 4. Often (once in } 2 \text { weelss) } \\
\text { 5. Very often (every week) }\end{array}$ \\
\hline 1 & Writing boards & 1223345 \\
\hline 2 & Roller boards & $\begin{array}{lllll}1 & 2 & 3 & 4 & 5\end{array}$ \\
\hline 3 & Printed materials & 122345 \\
\hline 4 & Overhead Projectors (OHP) & 122345 \\
\hline 5 & Transparencies & 1223345 \\
\hline 6 & Computers & $\begin{array}{lllll}1 & 2 & 3 & 4 & 5\end{array}$ \\
\hline 7 & LCD Projectors & 122345 \\
\hline 8 & Models & 12335 \\
\hline 9 & Magnetic boards & 122345 \\
\hline 10 & Pictures & 122345 \\
\hline 11 & Televisions & 122345 \\
\hline 12 & Radios & 122345 \\
\hline 13 & Compact Discs & 123345 \\
\hline 14 & Flash cards & 12345 \\
\hline 15 & Charts & 122345 \\
\hline 16 & Game materials & 122345 \\
\hline 17 & Actual equipment & 1223345 \\
\hline 18 & Websites & 122345 \\
\hline
\end{tabular}

Thank you for your time contribution and thoughts for answering honestly and sincere. 


\section{Appendix 2}

TEACHING PERSONNEL NEEDS ANALYSIS

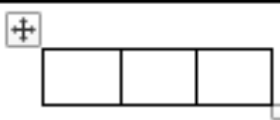
QUESTIONNAIRE

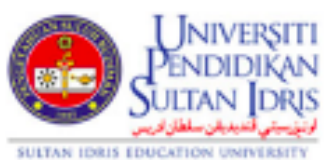

FEEDBACK ON ELECTRONIC TECHNOLOGY TEACHING PERSONNEL AT VOCATIONAL COLLEGE FOR DEVELOPMENT NEEDS OF A SPECIALISED LEARNING MODULE BASED ON INQUIRY APPROACH

By:

Anesman Buangraya Wenge bin Abdul Rahman

Faculty of Technical and vocational

Universiti Pendidikan Sultan Idris

The questionnaire is the need for analytical analysis (Need Analysis) which aims to gain instructor feedback on students ' needs on a survey-based learning module for the Repair and Maintenance Course of Electronic Hardware and ETN3033 course code. The study is aimed at identifying the level of use of teaching aids used by trainers based on the instructor's perception of electronic technology. Your cooperation is sincere and precisely appreciated. Information provided will be kept confidential and used for the benefit of this study only.

THIS QUESTIONNAIRE CONSISTS OF TWO (2) SECTIONS I.E. PART A TO PART B AS FOLLOWS:

PART A: RESPONDENT DEMOGRAPHICS PART B: TEACHING AIDS 


\section{PART A: RESPONDENT DEMOGRAPHICS}

Instructions: Please select one of the only answers and tick $(\sqrt{ })$ in the space provided.

1. Gender

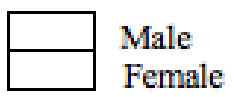

2. Age

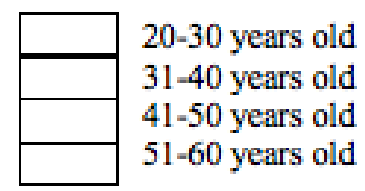

3. Duration of teaching experience in electronic field

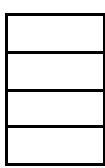

$1-5$ years old

6-10 years old

11-15 years old

$>15$ years old

4. Knowledge of Information and Communication Technology (ICT) skills

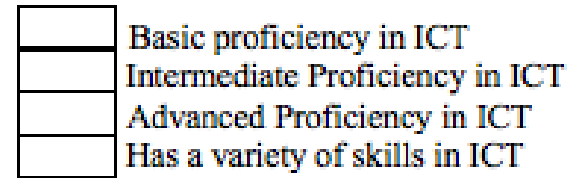

5. Have a personal computer/laptop

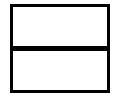

Have

No (please proceed to question 7)

6. If you have a computer, do the computer have Internet access

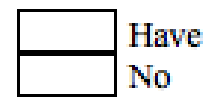

7. Computer skills

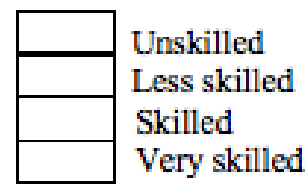


8. Do all the syllabus in the PPPE course be fully implemented according to the time frame prescribed in the Standard curriculum of the vocational college?

\begin{tabular}{|l|l}
\hline Be implemented \\
Cannot be implemented
\end{tabular}

9. Electronic Hardware Repair and Maintenance Course (ETN3033) has a learning module?

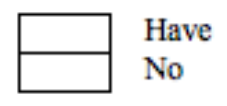

If any, are there any weaknesses or improvements to be done on the module? Please

specify:

10. Are there any requirements for the construction of the learning module for the repair and maintenance courses on electronic hardware online?

Need

No need

If it is necessary, is it important to be implemented in class? Please specify: 


\section{PART B: TEACHING AIDS}

Directions: This section to assess the frequency of teaching aids usage by trainers in the PPPE course.

Tick $(\sqrt{ })$ your answers based on the frequency scale provided.

\begin{tabular}{|c|c|c|}
\hline Number & $\begin{array}{l}\text { Teaching aids used in the PPPE } \\
\text { course }\end{array}$ & $\begin{array}{l}\text { Usage Frequency scale: } \\
\text { 1. Never } \\
\text { 2. Infrequently (once in } 6 \text { weeks) } \\
\text { 3. Sometimes (once in } 4 \text { weeks) } \\
\text { 4. Often (once in } 2 \text { weeks) } \\
\text { 5. Very often (every week) }\end{array}$ \\
\hline 1 & Writing boards & $\begin{array}{lllll}1 & 2 & 3 & 4 & 5\end{array}$ \\
\hline 2 & Roller boards & $\begin{array}{lllll} & 2 & 3 & 4 & 5\end{array}$ \\
\hline 3 & Printed materials & $\begin{array}{lllll}1 & 2 & 3 & 4 & 5\end{array}$ \\
\hline 4 & Overhead Projectors (OHP) & $\begin{array}{lllll} & 2 & 3 & 4 & 5\end{array}$ \\
\hline 5 & Transparencies & $\begin{array}{lllll} & 2 & 3 & 4 & 5\end{array}$ \\
\hline 6 & Computers & $\begin{array}{lllll}1 & 2 & 3 & 4 & 5\end{array}$ \\
\hline 7 & LCD Projectors & $\begin{array}{lllll}1 & 2 & 3 & 4 & 5\end{array}$ \\
\hline 8 & Models & $\begin{array}{lllll}1 & 2 & 3 & 4 & 5\end{array}$ \\
\hline 9 & Magnetic boards & $\begin{array}{lllll}1 & 2 & 3 & 4 & 5\end{array}$ \\
\hline 10 & Pictures & $\begin{array}{lllll}1 & 2 & 3 & 4 & 5\end{array}$ \\
\hline 11 & Televisions & $\begin{array}{lllll} & 2 & 3 & 4 & 5\end{array}$ \\
\hline 12 & Radios & $\begin{array}{lllll}1 & 2 & 3 & 4 & 5\end{array}$ \\
\hline 13 & Compact Discs & $\begin{array}{lllll}1 & 2 & 3 & 4 & 5\end{array}$ \\
\hline 14 & Flash cards & $\begin{array}{lllll}1 & 2 & 3 & 4 & 5\end{array}$ \\
\hline 15 & Charts & $\begin{array}{lllll} & 2 & 3 & 4 & 5\end{array}$ \\
\hline 16 & Game materials & $\begin{array}{lllll} & 2 & 3 & 4 & 5\end{array}$ \\
\hline 17 & Actual equipment & $\begin{array}{lllll} & 2 & 3 & 4 & 5\end{array}$ \\
\hline 18 & Websites & $\begin{array}{lllll} & 2 & 3 & 4 & 5\end{array}$ \\
\hline
\end{tabular}

Thank you for your time contribution and thoughts for answering honestly and sincere. 